\title{
Reform and Regulate the Telecommunications Services Sector in Algeria
}

\author{
Leila khaouani", Chaib Baghdad \\ Department of Economics, Tlemcen University, Algeria
}

Copyright $\mathrm{C} 2019$ by authors, all rights reserved. Authors agree that this article remains permanently open access under the terms of the Creative Commons Attribution License 4.0 International License

\begin{abstract}
The reform is a continuous process that changes with the development of markets, but are not seen as an application to one set of rules, as for instance administrative reform is the artificial inducement of administrative transformation against resistance that has existed ever since men conceived better ways of organizing their activities. The present study concerns the ITC services that allow people to be connected to manage their business, either commercial or personal. The problem is a necessity to reform this sector, which is controlled by the state according to the principals of auto-organisation. The aim of this article is to highlight the necessity existence of an independent entity of arbitration, with trying to overcom all barriers for this sector considered as the most important infrastructure in realising balanced (or equilibrated) development. The findings of our study summarized in the changing are inevitable to develop the ITC sector in Arab countries, where it is characterized by monopolistic given services. Algeria is among those countries that tried to organize its sector at the beginning of this century, by providing a good law context and making it more attractive for investments.
\end{abstract}

Keywords Regulation, Sector Services, Organization, Arab Countries, Reforms in Algeria

\section{Introduction}

Reform and change are similar in many respects, and it is not surprising that the words are used synonymously as for instance in this definition: "administrative reform" means any change of principles, organization structure, methods or procedures which it for improving the administrative process..., is a continued, sometimes hardly perceptible, change, a process of evolution and not a revolution (Gerald E. Caiden,2009).

We end from the above the need for administrative reform arises from the malfunctioning of the natural processes of administrative change. Reform movements begin with the intention of removing obstacles to change or of improving on the results of changes where it is being accommodated (Caiden, 2009).

Under the impact of technological change and the globalize networks, liberalization policies were initiated, first in the United States, Great Britain and Japan in the early 1980s, and then from the 1990s onwards. Regional level (Europe) and then global (Asia-Oceania, Americas, Africa). If for some countries this liberalization corresponds to the implementation of public policies adopted in the framework of a sovereign decision, otherwise it acts as a burden on multilateral policies aimed at global liberalization of the service sector. (Benamrane, Jaffré, \& Xavier, 2005)

In this context, changing economies are of particular interest given the size of the pressures and rapidity with which the economic landscape has been reshaped over the last two decades. At the time of globalization of trade and globalization, their integration is recognized as a capital to investors but in a societal change challenge. (Walter Amedzro St-hilaire, 2011)

Hence it highlights the need for global telecoms regulation which is a triggering factor in the development of mobile telephony in the changing economies, not forgetting that the telecom market in these countries has been dominated by natural monopoly theories since a long time.

\section{Literature Review}

In the recent past there have been quite a number of studies that have analyzed the regulation of telecommunications services sector on various countries like Algeria, Arab Countries, Senegal, Africa, and reforms regulation in MENA. For instance Williams, Mayer, and Minges, (2011) analyzed that the late 1990s the ICT sector in Africa has undergone political reforms by opening the sector to private investors this has allowed benefits such as: 
- Large-scale investment in the sector across the continent has transformed telecommunications into a luxury appreciated by a privileged number of a mass;

- Coverage of mobile networks increased from 16 per cent to 90 per cent of the urban population;

- Reduction of prices and adaptation of services according to the specific needs of the urban and rural population;

- Almost half of the rural population in Africa also lived in the range of a mobile network.

But this process is far from complete. Many countries still support a restriction on operators' activities in the telecommunications sector and in cases such as introduction an international operator gateway, effectively reverse the process of market liberalization that has been so successful. Moreover, the markers of sectorial policies turn to the Internet, while voice networks develop throughout the region. Finally, Africa's ICT infrastructure gathers these experiences and offers a series of policy recommendations that will support the continued development of the sector, particularly in the provision of affordable broadband Internet.

Baye Samba Diop (2012), in the framework of this study, the author has dealt with the development of telecommunications in Senegal. By adopting the telecommunications code in 2001, Senegal wanted to take a new step in the process of building a competitive telecommunications market. Before this date, after the world's step towards economic liberalism and the recommendations of its development partners, Senegal had already privatized the incumbent before opening the sector to competition.

In order to gain investor confidence, the Code first devoted itself to principles to make sure fair and reasonable competition, including transparency, non-discrimination, quality of service, price-to-cost orientation, and sound fair competition. Secondly, it has set up a regulator whose financing mechanisms, relations with the sector ministry, litigation prerogatives should make it possible to set up effective regulation in favor of reasonable competition.

To make sure to protect the public service, the legislature enshrined the obligation to respect the principles of continuity, availability and equality before the public telecommunications service. Guaranteeing the right to public service also concerned people living in disadvantaged areas, especially the rural population. For this, the legislature has put in place a mechanism to make sure universal service.

Senegal now has one of the best telecommunications infrastructures in the West African sub region and its market remains competitive. However, some weak players in the market suffer from the power of licensed operators, they are mainly telecommunications service providers.

According to Imed limam (2003), the economic and regulatory dynamics in the telecommunications is the subject of this study and the aim is to describe and analyze the strategies for the future developments of telecommunications sector in transition countries, to find out its special features, and based on these. He suggested adequate strategies for the future development of this sector. The empirical investigations focus on the whole group of transition countries with respect to key policy issues, Russia has been a special focus.

This research is focused on the strategic development in the three main directions: privatization, liberalization and regulation in telecommunications sector. Moreover, these processes are investigated in terms of three main telecommunications area: fixed telecommunications, mobile telecoms, as well as broadband infrastructure and content. Due to the convergence development, the borders between these three fields are blurring the special focus on Russia, the biggest country among transition countries.

The goal of the paper of Riad Dahel (2001), is to offer an overview of the privatization efforts undertaken by Arab countries in the telecommunications sector. The discussion is limited to telephone services, both fixed and mobile. Although most Arab countries have only recently made the commitment to privatize their telecommunications services, they have already made some progress toward reaching that objective.

Regarding mobile services, the extent of private sector participation in this segment of telecommunications is significant. Except for Oman, Saudi Arabia and Tunisia where mobile services are provided by the public telecommunications company, all other countries have private involvement in the segment. The latter is structured either as a monopoly (Bahrain, Mauritania, Qatar, Sudan and UAE) or as a duopoly (Algeria, Egypt, Kuwait, Lebanon, Syria, Jordan, Morocco and Yemen). However, this structure is expected to change in most countries as exclusivity periods granted to private firms under the terms of the contracts are relatively short. This will allow governments to sell other licenses, thus increasing competition in mobile services.

Overall, although most Arab countries have only recently made the commitment to privatize their telecommunications services, they have already made some progress toward reaching that objective. Furthermore, most Arab countries have either adopted new telecommunications laws or modified the existing ones in order to offer a proper legal and regulatory framework for the expand of the sector.

Concerning Berry Nourredine (2010), the main objective of this study is to strike a balance between the opening up to competition of this sector and the need of public service. The search for this balance takes place through the notion of regulation which constitutes a new function, aiming to reconcile two contradictory goals: openness to competition and the general interest.

The author has developed two parts by concluding that the regulation of the public telecommunications service in Algeria seems dominated by an economic conception 
which considers the public service as the justification of the monopoly incompatible with the liberalization and the construction of the competitive market. The sectoral regulation developed by the public authorities and the new regulatory authority can still reconcile the idea of public service and to liberalize the telecom market. Governments should no longer simply state many principles that contribute to or protect the public service, but should also consider the effective mechanisms for its protection.

The type of regulation adopted in our country, in the telecommunications sector, is a type of politico-administrative model in which regulation is an integral part of the government's policy process. For effective regulation to take place in this particular sector of telecommunications, the government still has to provide the regulator with effective organizational and functional independence, remove the ambiguities relating to the sharing of powers with the general competition authority and ultimately, to activate and reactivate the Council of competition to build an Algerian competition and regulatory case law.

From what precedes this paper, it is clear that the State attached itself to former public service missions but in a competitive climate.

\section{Regulate the Telecommunications Services Sector}

Regulation is a system of governance that encompasses a new concept for the social sciences. It is used in scientific language, in embryology as in physiology (thermal regulation), (Abdou Salam Sall, 2007). In mechanics, regulation expresses the fact of acting on a complex system and of coordinating its actions in order to maintain its equilibrium, to adapt it to the circumstances and to obtain a correct functioning in view of its objectives.

The regulation in telecommunications, according to Thierry Penard and Nicolas Thiron (2007), concerned three areas:

- The desire to create and maintain effective competition in the markets concerned;

- The need to retain some control over the production and evolution of it;

- The concern to ensure some redistribution in favor of the specific categories of populations or territories.

\subsection{Factors Changing the Telecommunication System}

In recent years, the field of telecommunications has shown a trend contrary to what it was in the past, meaning that the state is moving from a dominant to a state of a single function working as business organizer or manager and this is caused by several factors that can be summarized as follows:

\subsubsection{Technological Factors}

Technological development is a starting point in the organization of communications and is increasing the demand for its services, especially new ones such as digitization, fiber optics, satellites, peripherals ... and others. Technological development is based on innovations in electronic methods such as informatics and telematics ${ }^{1}$ in office and automation, and it is a new type of technology which at the same time includes improved products and means of conversion in economic structures.

\subsubsection{Economic Factors}

They represent market laws, which are governed by the supply and demand mechanism, are that the latter has evolved considerably, mainly because of the technological wealth that has affected the sector.

\subsubsection{Institutional Factors}

Economic and technological factors have paved the way for institutional changes in order for the telecommunications sector to keep up with new developments, so that these variables have become necessary.

\subsection{How to Regulate Telecommunications}

The choice to reorganize the sector depends on several factors, cited below:

- The nature of telecommunications and its rights policies.

- Policy and institutional framework, and the general principles of economic policy and goals.

- The provision of financial and human resources to cope with new administrative activities;

- $\quad$ Opening up to competition, while maintaining public telecommunications operators on the market.

Several countries have begun to restructure the public telecommunications sector, and they have continued with varying degrees, whether Arab or foreign countries, and from this point of view, we will discuss some choices for restructuring public sector telecommunications.

\subsubsection{Privatization of the Sector}

Even though the concept of privatization in the legal, economic, social and media literature has received a variety of meanings, the notion of privatization of public enterprises is defined as an operation by the control exercised, directly or indirectly, by the public authorities on an organization of human, material and immaterial means devoted to the exclusive or principal exercise of an economic activity, and transferred to the private sector

1 The branch of information technology that deals with the long-distance transmission of computerized information, this transformation will make telematics an essential element of a new generation of personalized mobile services. 
(Nicolas Thirion, 2000).Privatization in the broad sense is the transfer of an activity, establishment or undertaking from the public sector to the private sector through the sale of assets. The ideological objectives of privatization can be multiple (Toupictionnaire: the dictionary of politics):

- Reduce state intervention in the economy.

- Open up to competition an area of activity that had previously been monopolistic;

- $\quad$ Provide more flexibility to companies (appointment of officers, decision-making);

- Provide more revenue to the State (but only once).

The forms of privatization are different from one country to another (see kjell, Eliassen and John, 2007), they are considered unlike nationalization ${ }^{2}$ operated in Europe and other places, and especially after the Second World War, privatization in the telecommunications sector must have the legal framework in line with the principles of competition and through the participation of the State as a provider of services in the market, with the possibility of the private sector entry. The incentives for privatization have been outlined as follows (Imed limam, 2003):

- To improve the efficient operation of public assets and services by involving the private sector in management;

- To raise money for the government or to reduce government expenditures;

- To stimulate capital market development and thereby widen investment opportunities for the private sector;

- To free public enterprises from the investment constraints inherent in government finance;

- To introduce competition in undertakings previously carried out by state-owned monopolies.

\subsubsection{Sector Liberalization}

Many countries around the world have opted to regulate their telecommunications sector through the liberalization policy while maintaining basic services. The liberalization is a process of determining a series of amendments that have been added to a public policy and regulatory rules that would allow the public and private sectors to work effectively to serve the public interest, liberalization in the concept differs from privatization, since it expressed the end of the monopoly and recognizing the right of private sector activity.

In the field of telecommunications, liberalization represents a sort of abduction the services of the sector that are under the responsibility of public enterprises become flexible by giving all participants, whether public or private, an appropriate market position, on condition of improving telecommunication within the same country in general, and in order to widen the services for the realization the efficiency in the administration in particular . The process of liberalizing telecommunications is a gradual process,

2 Nationalization in the broadest sense, the development of an activity under public control. even if it is done in a partial way, it aims to:

- Work with the rules of the market economy in telecoms management provided to develop new services and create the conditions to growth.

- The expand of networks and basic services to promote the necessary investment;

- Develop the basic network in each country, taking into account the financial security provided by suppliers;

- Increase efficiency and improve service quality that affects positively the economic and social development. Create Companies

The point requires legal changes so that the operator can take administrative and financial independence and become independent. It can also take the nature of a public limited company which is wholly owned by the government or take the character of a state-owned holding company; the purpose of this change is to increase the capital or to partner with the private sector.

\subsubsection{Regulate the Sector in the Form of Hybrid Models}

This form combines the concept of competition with the concept of public service, what provides an open network works effective competition rules, and to ensure free access to public network operators, this type of model has been adopted by the countries of Latin America and Europe. The implications of mixed models are summarized in the following points:

- Recognize the existence of diversity in the activity of the sector, and the traditional operator can work with other service providers;

- Distinguish between sector services and basic services, public and private services and value-added services;

- Ensure access to all operators for transparency and equality;

- Partial liberalization of a number of network items for the development of the telecommunications industry (e.g. terminal equipment).

\section{Telecommunications Reform}

Since the beginning of the 1990, the telecommunications operator in many countries has been state owned, and with the emergence of restructuring options for the public sector, represented by the privatization process, corporate creation and sector liberalization, the need for an independent arbitrator body has become urgent, these changes represent the first step towards new policies.

\subsection{Guidelines for Reform}

The reform of the telecommunications sector has taken different forms in each country depending on the circumstances surrounding it, and aims to: 
- Separate of postal and telecommunications interests.

- Separate between the roles of the operator, the regulator and the policy maker, so that the role of the state is limited to issues related to telecommunications policy in the broad sense, and decentralization leads to increased efficiency in network and service infrastructure management.

- To stimulate investment in the telecommunications sector as an influential force in economic development;

- Open the sector to competition in order to diversify the elements involved in the market both public and private, which requires a flexible legal framework for these purposes in order to accommodate changes resulting from technological progress;

- The need for cooperation between different countries to benefit from their experience.

To agree with all previous considerations and the need for telecommunications reform, work has begun on the creation of separate regulatory bodies at a time when the responsibilities of the Ministry of Sector are diminishing. Despite these transformations, the nature of the basic telecommunications services in Arab countries is often monopolistic, no matter what current operator is wholly or partly owned by the State.

\subsection{Administrative Reform}

Administrative reform requires reform of the legal, regulatory and public telecommunications operators so that the department can implement the decisions according to the policies developed, this type of reform requires appropriate management of the new environment that can be derived from the traditional type of management. The new legal and regulatory environment requires an appropriate type of autonomous department to implement the law and subsequent regulations, the department should therefore follow procedures that are best suited to its specific functions, and reforming its sector in line with a more open competitive environment based on the development of value-added services, enables the sector to open large segments of the market to free competition. In addition, the expansion and diversification of services allows the country to own the telecommunications sector, by introducing new laws and regulatory mechanisms that we review as follows.

\subsubsection{Legal Provisions}

Administrative reform requires new or appropriate laws with a full range of features according to the policies that are used to develop and keep pace with technological changes in the field of telecommunications as a dynamic sector. The telecom law should create an attractive environment for foreign investment, and be consistent with the transformation of the role of the state in contemporary society, the development and promulgation of the telecommunications sector act involves a series of processes that are consistent with the constitutional framework. (Arab Book, 2008)

\subsubsection{Regulatory Provisions}

These provisions are divided into general regulatory provisions, encouraging regulatory provisions and provisions for public telecommunication operators.

\subsubsection{Develop a Regulatory Body}

It regulates the sector without continuing its operation, leading to a variety of sector participants, such as the State, suppliers of services and goods, and public and private operators, this diversity leads us to competition, which is the condition of the new legal framework for telecommunication management that serves the long-term interests of the public. Under the new telecommunications act, we find a set of models for the development of the regulatory body such as the governmental regulatory body and independent regulatory body like the Federal Communications Commission (FCC) ${ }^{3}$ the lost regulatory body, and the self-regulatory body.

\subsection{Human Resource Management}

The human element is seen as the best service for the telecommunications sector and the main resource is highly considered for increasing the efficiency of employees to keep pace with administrative and strategic development. The managed of human resources in Arab countries has sometimes led to the import of foreign expertise due to lack of national skills trained in the field of modern telecommunications due to the rapid technological development of the network, and the reform they know in which many Arab countries find the training process inconsistent with the management strategy therefore which ended by giving more importance to personal and collective performance by identifying responsibilities and strengthening Arab cooperation with international organizations and the International Telecommunication Union in order to benefit from their experience in the field of human resources development through the provision of training programs.

Training is not limited to this area only, but must include the institution in general, as well as the use of new patterns such as distance training and training using the network. Although there are many similarities in the Arab region, there are no law aspects that differ from country to another and countries that are making reforms benefit from the experiences of countries that have embarked on legislative reforms by taking positive sides and addressing problems arising from operating under the new telecommunications sector reform architecture.

3 FCC: Federal Communications Commission of the United States established under the Telecommunications Act of 1934 amended in 1996. 


\section{The Status of Telecommunications in Algeria before Change}

Since the accession of Algeria to independence in 1962, the telecommunications sector has encountered several obstacles because the inherited network was in the interests of French colonialism and the notion of public service was distorted because most Algerians did not take advantage. Then Algeria pursued development plans to be able to meet urgent needs and eliminate the accumulated delays, the first three-year plan saw some achievements including the creation of telephone centers and switching centers.

Telephone density was estimated in 1969 at 0.68 lines per 100 inhabitants, a decrease from 1961 (1.01 lines per 100 inhabitants), due to the intensified migration of Europeans after independence who represent the majority of participants. (MPT, 1985) In terms of skilled workers, there was a shortage, despite the training effort, such as the construction of the Central School of Algiers in 1964. Adding to this the reduction of skilled manpower of foreigners due to the security situation, as a result of espionage operations that have occurred, this situation adversely affects the quality of the services provided.

The basic guideline for the quadrennial development plan is the reform of the network which is outdated as a whole and to develop it so that it can meet the needs of the country in due course. The telephone density is 1.4 lines per 100 inhabitants and the telex has increased so that the number of subscribers has increased from 212 lines for the year 1961 to 2,400 lines at the end of 1979. The disadvantage of that period, disturbances in the implementation of the second four-year plan during the administrative division of 1974 , so that the number of wilayas (city) rose from 15 to 31 , which led to an imbalance in the telecommunication system with this new number and the sector's objectives have not seen a change. (MPT, 1981)

The number of subscribers also increased in the 1980s and the telephone density was estimated at 2.9 lines per hundred inhabitants at the end of 1989, and equipment also increased by $5 \%$, due to delay in the completion of the buildings of the telephone centers which were supposed to receive a large number of programmed equipment.The waiting list of the application was estimated at the end of 1989 to 604,251 request, from here we can see the magnitude of numeral in relation to the number of subscribers for the same period, is 732,721 subscriber, and the imbalance between supply and demand is due on the to the administrative division of 1984 , whose number of wilayas rose from 31 to 48 and the saturation of the system of numbering of the telephone network at the end of 1989.

The quinquennial plans of the 1990s also saw growth in the telex network, so that the number of subscribers was 12 605 telephone lines at the end of 1999, although the first nineties saw a decline in demand mainly due to the widespread use of telecopy, this phenomenon has spread not only in Algeria but even in the world

The telephone density was estimated at $5.35 \%$ in 1999 , but it is still far behind the value identified in the planned objectives, adding to this the pending application (731.377) this mainly explains the degree of saturation in cables and transformers. At the level of the transit network which operates on the driving of the movement, its equipment has remained unchanged since 1979 unlike the national network of subscribers.

\section{Telecommunications Sector Reform}

The sector has been monopolized by the state and has suffered greatly in response to the growing demand for telephone lines. But things have changed thanks to the new law of the telecommunications sector, which opened the doors to private investors after thirty eight years, the State has licensed the private sector, and led to increased supply in this area.

\subsection{Legal Framework for Liberalization of the Telecommunications Sector}

The law $\mathrm{n}{ }^{\circ}$ 03-2000 of August 5, 2000 (The Official Gazette, 2000) was aiming on opening competition and the promotion of private investments in the field of telecommunications, in this context, the company Algeria Telecoms (SPA) was created within the framework of the law quoted above, as well as the decision of the National Council of State Contributions (CNPE) dated 1 March 2001, which provided for the establishment of a public economic institution called "Algeria Telecom" which defines the general economic institutional system according to the legal formula for the actions of the institution.

The effect of this change is to create the authority of the regulation ${ }^{4}$ of postal and telecommunications, in accordance with the previous law and is an independent institution with a legal personality and financial authority confined to tasks in the following areas:

- Ensure effective and legitimate competition, while taking all measures to improve the postal and telecommunications markets;

- Ensure the application of the specifications between service operators, respect for the principle of non-discrimination and control of the management of funds;

- The management of tendering procedures in the operation of public telecommunications networks that are licensed, specifying the standards to be provided;

4 The regulatory authority is an independent institution and the Head of State appoints its officers, among the functions of the authority is to ensure the adjustment of the activity of the sector, and guarantees effective competition, and to determine the laws Which can be applied by the network operators of the sector in order to define the services offered to the public, and to perform other tasks..... 
- Express an opinion on the maximum tariff for postal and telecommunications, and adapt development strategies if necessary.

In 2000, the Regulatory Authority set out to pave the way for operators gradually to compete in the postal and telecommunications sector.Since 2001, the regulatory authority has started licensing for mobile phone (GSM), fixed, then $\mathrm{VSAT}^{5}$ and $\mathrm{GMPCS}^{6}$, and licensing for Internet service providers and audiotex and converts audio through Internet protocol and call centers.

These licenses granted to private operators, in order to establish and operate a public telecommunications network, and with the cooperation of the Ministry of Posts and Information and Communication Technologies, in accordance with its validity provided. These procedures are subject to the organization of calls for competition in two phases, pre-qualification phase, and supply phase.

The license system (mandate and authorization) are subject to the conditions set by the regulatory authority, all this is considered a leap achieved by the post and telecommunications sector, so that it has created a lot of jobs that make increase the level of the economic welfare of the citizen.

\subsection{The Reality of Telecommunications in Algeria}

The sector has developed since the publication of the law 03-2000, which allows opening the sector to competition.

\subsubsection{Evolution of Telephone Network}

The sector was opened to three operators and allowed a high telephone density in recent years, the fixed telephone has achieved an increase so that the density increased from $5.80 \%$ in 2000 to $8.29 \%$ in 2011 which is due to the new competitor on the market such as the Egyptian operator Djezzy Telecom plus the public operator Algeria Telecom,

Which allowed the number of subscribers to increase from 1.880 million Subscribers in 2000 to 3,059 million subscribers in 2011, the table below shows us that.

5 VSAT means of telecommunication network with satellite in fixed orbit assure its station HUB The access to the conduct of the stations of space capacity VSAT.

6 GMPCS all means of satellite system in fixed or non-fixed international or regional orbit, leased or hosted by the licensee and capable of providing mobile services for telecommunications directly to end-users. 
Table1. Evolution and Penetration of Fixed Telephony

\begin{tabular}{|c|c|c|c|c|c|}
\hline Year & 2001 & 2002 & 2003 & 2004 & 2005 \\
\hline landline & 1880200 & 1950000 & 2079464 & 2486720 & 2572000 \\
\hline Density & - & $6,10 \%$ & $6,90 \%$ & $7,63 \%$ & $7,81 \%$ \\
\hline 2006 & 2007 & 2008 & 2009 & 2010 & 2011 \\
\hline 2841297 & 3068409 & 3069140 & 2576165 & 2922731 & 3059366 \\
\hline $8,06 \%$ & $9,10 \%$ & $9,00 \%$ & $7,22 \%$ & $8,10 \%$ & $8,29 \%$ \\
\hline Year & 2012 & 2013 & 2014 & 2015 & 2016 \\
\hline landline & 3231332 & 3138914 & 3098787 & 3267592 & 3404709 \\
\hline density & 8,55 & 8,11 & 7,80 & 8,09 & 8,26 \\
\hline
\end{tabular}

Source: ARPT (2016)

According to the figure below, the number of subscribers to the fixed network at the end of 2015 is 3,268 million, an increase of $4.45 \%$ compared to 2014 which had 3,099 million subscribers. The penetration rate at the end of 2015 is $8.09 \%$.

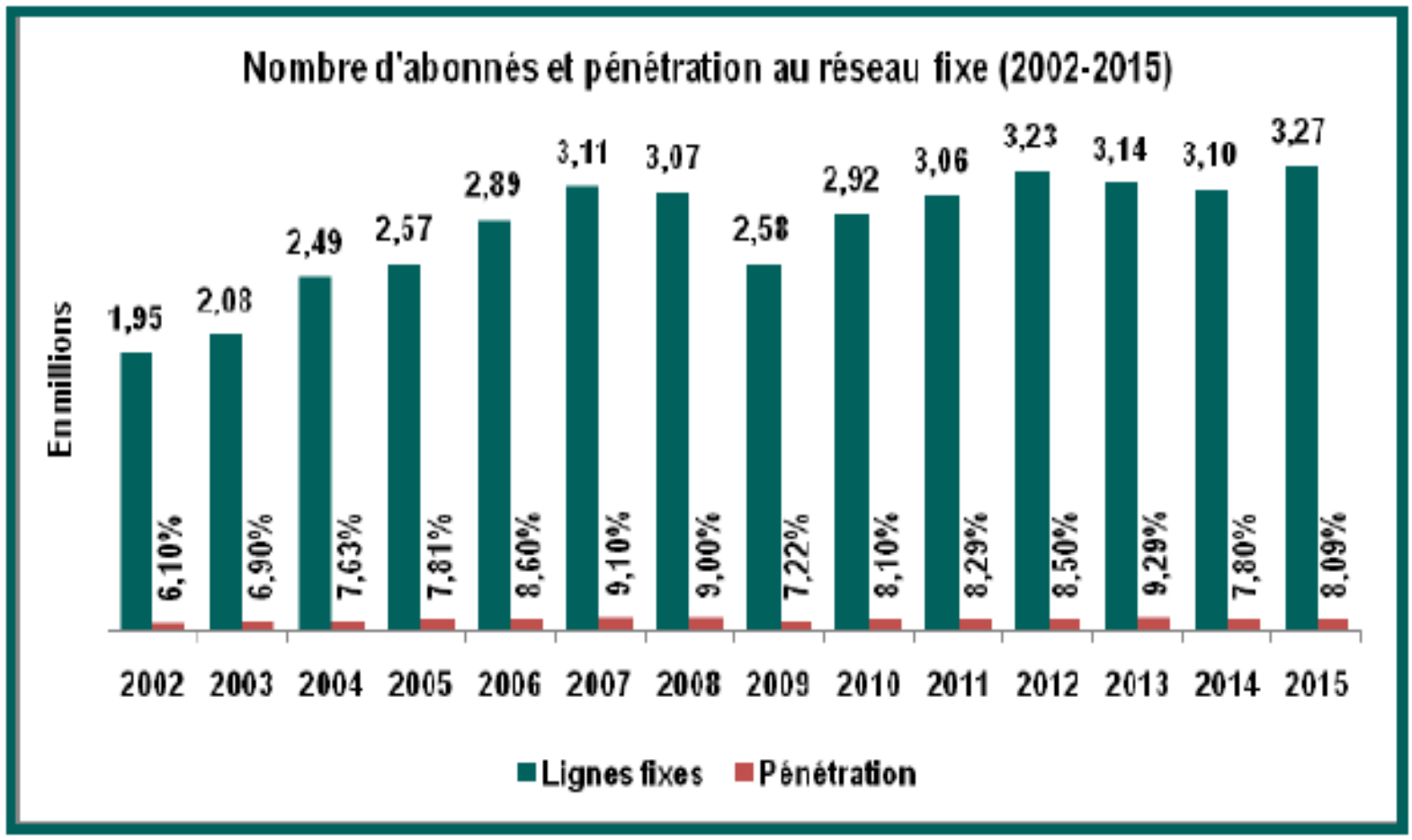

Source: ARPT (2015)

Figure 1. Number of Subscribers and Fixed Network Penetration (2002-2015) 
The number of subscribers to the fixed network has remained relatively stagnant since the opening of mobile telephony market. The latter is better suited to the needs of the market thanks to its numerous advantages (mobility, SMS, value added services, mobile Internet).

The mobile phone saw an expansion from $0.28 \%$ in 2000 to $96.52 \%$ in 2011 , due to the pre-card payment system that was preferred by the subscriber because of easy mobility and low consumption cost, each operator propose more attractive offers than others such as prices per second and periodic reductions making the number of subscribers to reach 35,615 million subscribers in the mobile network in Algeria in 2011, recording an increase of 2.5 million users compared to 2010,according to the agency, the regulatory authority(ARPT, 2013).

These data indicate that the proportion of more than 96.5 percent of the population benefited from the mobile services offered by the three operators, Algeria Telecom (public) and Orascom Telecom-Djezzy (private) and wataniya Telecom - Nedjma (private).

According to Table 2, in the year 2014 the number of subscribers reach 43.298 million subscribers with a telephone density estimated at $109,62 \%$. This is due to the three operators represented by Wataniya Telecom Algeria with an estimated 11. 663.731 subscribers, Orascom Telecom Algeria acquires the largest share of 18612148 subscribers, and Algeria Telecom's share of the mobile market is 13.222 .295 subscribers.

In the year 2015, the mobile phone market declined by $0,16 \%$ from 43,298 million subscribers in 2014 to 43,228 million subscribers. This decrease is mainly due to the deactivation of the lines relating to the inactive and unidentified subscribers of the three operators.

The mobile phone density (GSM \& 3G) saw a decrease of $2,39 \%$, from $109,62 \%$ to $107 \%$. In terms of market share relative to the subscriber base (GSM \& 3G), the operator (OTA) leads the telephony market with $38.43 \%$, followed by (ATM) and (WTA) respectively with $33,12 \%$ and $28,45 \%$.

In terms of the breakdown by type of technology, GSM subscriber base amounted to 26,909 million subscribers in 2015 , a decrease of $22,65 \%$ compared to the previous year. This decrease is mainly due to subscriber move to third-generation $(3 \mathrm{G})$ networks.

The commercialization of 3G began in December 2013 for the (ATM) and (WTA) operators and in July 2014 for the operator (OTA). In 2015, the 3G subscriber base amounted to 16,319 million subscribers. On 31/12/2015, the operator (OTA) with $46.33 \%$ remains the leader in the GSM market, followed respectively by (ATM) and (WTA) with $28.90 \%$ and $24.77 \%$ respectively. (ARPT, 2015)

\subsubsection{Total Subscriber Base for Fixed and Mobile Networks}

The number of subscribers to fixed and mobile networks reached 50,446 million subscribers in 2016, compared with 46,659 million subscribers in 2015 , an increase of 3,787 million subscribers. This is mainly due to the expansion of the $3 \mathrm{G}$ subscriber base and the launch of $4 \mathrm{G}$ services. Tele-density to fixed and mobile networks will be $121,56 \%$ 2016, compared with $115,49 \%$ in 2015.

Table 2. Evolution and Spread of Mobile Phone

\begin{tabular}{|c|c|c|c|c|c|}
\hline \multirow{2}{*}{ year } & \multirow{2}{*}{$\begin{array}{c}\text { Total number of } \\
\text { subscribers }\end{array}$} & $\begin{array}{c}\text { Wataniya Telecom } \\
\text { Algeria (WTA) }\end{array}$ & $\begin{array}{c}\text { Orascom Telecom Algeria } \\
\text { (OTA) }\end{array}$ & $\begin{array}{c}\text { Algeria Telecom } \\
\text { Algeria (ATM) }\end{array}$ & \multirow{2}{*}{ Density \% } \\
\hline 1998 & 18000 & - & - & 18000 & 0,06 \\
\hline 1999 & 72000 & - & - & 72000 & 0,24 \\
\hline 2000 & 86000 & - & - & 86000 & 0,28 \\
\hline 2001 & 100000 & - & - & 100000 & 0,32 \\
\hline 2002 & 135204 & 315040 & - & 446924 & 1,5 \\
\hline 2003 & 167662 & 1279265 & 287562 & 13661355 & 4,67 \\
\hline 2004 & 1176485 & 3418367 & 1476561 & 20997954 & 41,52 \\
\hline 2005 & 4907960 & 7276834 & 2991024 & 27562721 & 63,6 \\
\hline 2006 & 7476104 & 10530826 & 4487706 & 27031472 & 81,5 \\
\hline 2007 & 9692762 & 13382253 & 5218926 & 32729824 & 79,04 \\
\hline 2008 & 7703689 & 14108857 & 8032682 & 32780165 & 91,68 \\
\hline 2009 & 10079500 & 14617642 & 8245998 & 35615926 & 90,3 \\
\hline 2010 & 9446774 & 15087393 & 8504779 & 37527703 & 96,52 \\
\hline 2011 & 10515914 & 16595233 & 9059150 & 39630347 & 99,28 \\
\hline 2012 & 10622884 & 17845669 & 9506545 & 43298174 & 102,40 \\
\hline 2013 & 12538475 & 17585327 & 11663731 & 43227643 & 109,62 \\
\hline 2014 & 13022295 & 18612148 & 12298360 & 47041321 & 107,00 \\
\hline 2015 & 14318169 & 16611115 & 13328689 & & 113,35 \\
\hline 2016 & 17344746 & 16367886 & & & \\
\hline
\end{tabular}



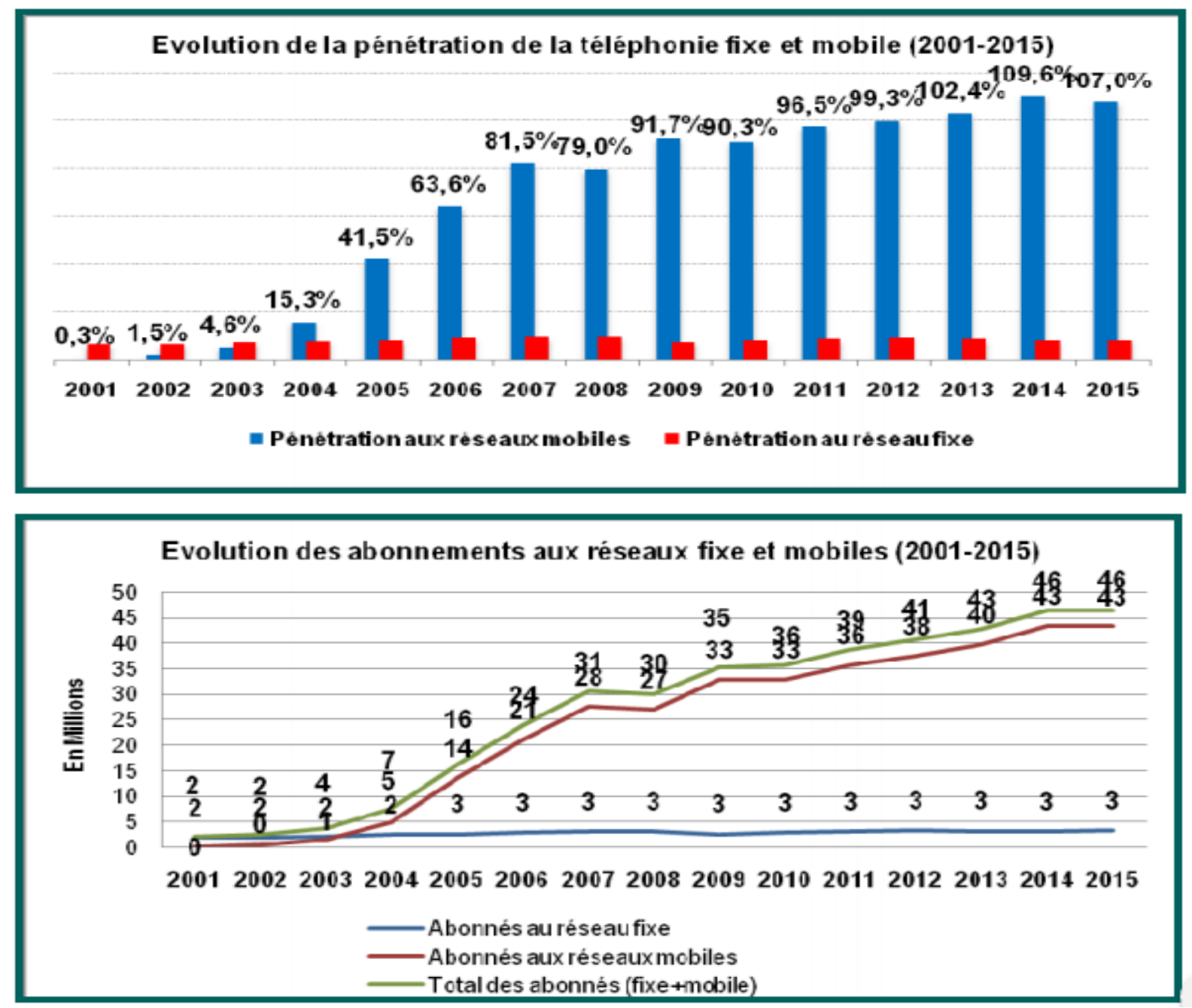

Source: ARPT (2015)

Figure 2. Evolution of Subscribers and Density for the Fixed and Mobile Telephone

According to the figures above, the telecommunications market was marked by stagnation in the year 2015 compared to previous years, in terms of number of subscribers to the fixed and mobile networks. This increased from 46, 4 million subscribers in 2014 to 46,49 million subscribers for the following year, a very slight increase of $0,21 \%$. This situation has slightly impacted the overall penetration rate, which reached $115,09 \%$ in 2015 , compared with $117.46 \%$ in 2014 , equivalent to 115 subscribers per 100 inhabitants (of which 107 subscribed to mobile telephony compared with 8 home phone). Notwithstanding the situation of the subscriber fleets, the traffic exchanged between subscribers of the fixed and mobile networks has grown significantly.

It rose from 91,528 billion minutes in 2014 to 119,468 billion minutes in 2015, an increase of $32,52 \%$ compared to 2014. In terms of market shares between types of fixed and mobile telephony, mobile telephony accounts for almost $92,97 \%$ of the national telephone network, compared to the fixed rate of only 7, $03 \%$. The contribution of the two segments makes it possible to ensure a total telephone tele-density of 115, 09\% for 2015 .

\subsubsection{Receipts or Income}

It should be noted that revenues generated by fixed and mobile telephony operators for the year 2014 amounted to more than 416 billion DA, which represents approximately $85 \%$ of the consolidated revenues of the sector (ARPT, 2014).

The consolidated revenue (provisional) generated in 2016 by the four operators operating in the fixed and mobile segments amounts to 444 billion dinars, against 433 billion dinars realized in 2015, an increase of 11 billion dinars In absolute value, this represent a growth rate of 2 , $54 \%$ which is mainly due to the growth in $3 \mathrm{G}$ and $4 \mathrm{G}$ fleets (fixed and mobile). As regards the contribution of the telecommunications sector to the gross domestic product (GDP) for 2014, it is estimated at 2, $91 \%$, and for 2015 is estimated at $3,17 \%$. 


\subsubsection{Evolution of the Internet}

Many Internet providers (ISP) have switched to ADSL technology, in other words high-speed Internet. This technology was introduced in Algeria in 2003 and the first supplier is EEPAD in partnership with Algeria Telecom (AT), followed by"Fawri" service in 2005 "Djawab" in partnership with Chinese "HUAWEI".

In 2005, EEPAD acquired $87 \%$ of the ADSL market, compared to $13 \%$ for Algeria Telecom. As for high-speed internet distributed through wired connections and VSAT connections, which have 100 customers for the three operators (Algeria telecoms, Orascom and Divona Algeria)and 3000 wired links to Algeria Telecom.

According to reports prepared in the first quarter of 2006, collected by the Regulatory Authority for Posts and Telecommunications, 39 Internet service providers were counted throughout the national territory, and 15 of them provided the service (ARPT, 2006). The field of the Internet has also made positive progress in several fields, as reflected in the report of the United Nations Conference on Trade and Development (United Nations, 2009), Algeria has been ranked among the five countries in Africa, which includes $90 \%$ of Internet subscribers with a fast flow next to Morocco, Tunisia, Egypt and South Africa, and this was the result of several operations to improve, develop, organize and make a heavy effort to develop and expand national and international telecommunications networks.

Public or private companies have been able to choose to expand their fiber optic networks so that more than 83,000 broadband Internet connections have been exploited for these customers, So that the number of the latter went from 19.000 in 2005 to 32.500 in 2013 , an increase of $71 \%$ during this period. The commercial network has been strengthened, moving from 225 in 2005 to 341 in 2013.

The availability of high-speed internet has increased from $1 \%$ in 2005 to $20 \%$ in 2013 , and the number of high-speed internet devices has moved from 56.000 in 2005 to 1.309 .454 at the end of March 2013, as for the number of high-speed internet customers has moved from 178.707 customers at the end of 2007 to 1.188 .201 in March 2013 Where $60 \%$ of them benefit from the fast-flowing Internet service with a WIFI modem. (Riad Dahel, 2001)

According to the below table, recent years have witnessed a change in the Internet market, with a penetration rate of $24,85 \%$ in 2014 , equivalent to 9816143 subscribers, compared to $6,04 \%$ at the end of December2013 where the number of subscribers reached 2339338 , an increase of 7476805 subscribers in less than a year. The mobile network witnessed an increase in subscribers from 1038700 in 2013 to 8231905 subscribers in 2014,which is due to the number of equipment third-generation (represented in tablet and smart phones) increased by $154 \%$ compared to 2013 (ARPT, 2014).
Table 3. Internet Market

\begin{tabular}{|c|c|c|}
\hline Internet subscribers & $\begin{array}{c}\text { Number of } \\
\text { subscribers } \\
\text { (Nov 2014) }\end{array}$ & $\begin{array}{c}\text { Number of } \\
\text { subscribers } \\
\text { (Dec 2013) }\end{array}$ \\
\hline ADSL (Fixed network) & 1510273 & 1297868 \\
\hline $\begin{array}{c}\text { Internet and mobile } \\
\text { network }\end{array}$ & 8231905 & 1038700 \\
\hline $\begin{array}{c}\text { High fixe debit (4G) } \\
\text { WIMAX }\end{array}$ & 21402 & - \\
\hline VSAT & 5816143 & 2339338 \\
\hline $\begin{array}{c}\text { Total internet subscribers } \\
\text { (\%Internet access } \\
\text { reported to the } \\
\text { population) }\end{array}$ & $24,85 \%$ & $6,04 \%$ \\
\hline
\end{tabular}

Source: ARPT (2014)

In 2016, mobile Internet density reached 64,28\%, a net increase of $23,28 \%$ compared to the previous year. This is due to the increase in subscribers to $3 \mathrm{G}$ and $4 \mathrm{G}$ networks. The total numbers of subscribers to fixed and mobile internet reached 29,539 million subscribers at the end of December 2016, against 18,947 million subscribers in 2015, an increase of 10,592 million subscribers. This is mainly due to the move of GSM subscribers to $3 \mathrm{G}$ and $4 \mathrm{G}$ networks. As for the distribution of these networks, it should be noted that $90,32 \%$ are mobile Internet subscribers (26,680 million subscribers), compared with $9,68 \%$ fixed Internet subscribers. The overall Internet density was $71,17 \%$ in 2016 , compared with $46,9 \%$ in 2015. This development can be explained in particular by the growth of subscribers $3 \mathrm{G}$ and $4 \mathrm{G}$ fixed and mobile.

\subsubsection{Value-added or Improved Services}

*Audiotex Services is a "one-way or interactive communication service between a subscriber in the telephone network and a machine that handles speech recognition and reconfiguration of voice messages" (ARPT, 2005 ) and received 45 registration certificates for audiotex customers to be exploited until 20 March 2005 in accordance with the provisions of Article 40 of Executive Decree No. 123-01 of 9 May 2001, followed by executive Decree No. 05-98 of the first decree, which was the subject of audiotex licensing services, came into force and 16 new registrants joined the new system by submitting new files.

*wimax this technology replaces the radio loop, allowing to achieve fixed Hertzian links at long distances estimated at $50 \mathrm{~km}$ and at a speed of about $75 \mathrm{MB} /$ second, and make local coverage from its base stations, the regulation authority granted the wimax licenses in the 3.5 $\mathrm{GHz}$ package, and the beneficiaries are represented in the following (ARPT, 2006):

- VoIP dealers;

- The two fixed operators represented by the Algerian Association and Algeria Telecom. 
*Networks (VSAT) opened to competition in 2004, in accordance with Law 2000-03, for the public telecommunications network and by operating through VSAT type for earth stations, and the dealers of this network are as follows:

- Divona Algeria acquires $25 \%$ of the market, and its customers are distributed across 20 wilayas.

- Orascom Telecom Algeria, which accounts for 17\% of the market, and its 46 clients are mainly concentrated in Algiers;

- Algeria Telecom acquires 58\% of the market and its customers are public institutions and official body and have set a timetable to cover 24 wilayas in the first year, followed by the second year by 36 wilayas, and finally 48 wilayas in the third year.

*General Mobile Personal Calls Satellite (GMPCS), This service is initially in the hands of Algeria Telecom and the regulatory authority has granted licenses to create and operate GMPS networks and are as follows:

- The first French mobile company via satellite (FTMCS), according to Executive Decree No. 31-05 of 2005.

- The second company of Al-Thuraya Satellite telecommunications Algeria, In accordance with Executive Decree 33-05 of 24 January 2005.

In addition to the Algerian Telecom Operator, whose status has been settled pursuant to Executive Decree 33-05 of January 24, 2005, the three operators constitute a mobile telephone environment on the satellite to cover the national coverage of their subscribers.

*Interconnection is "mutual services provided by operators of networks open to the public, which allow all users to freely communicate with each other regardless of the networks or services they use" (ARPT, 2006). The legal and regulatory framework relating to interconnection in Algeria, derived from Executive Decree 156-02 of 09 May 2002, aims to protect the operation, maintenance of network integration, and compatibility of services. There are two types of interconnection operators are:

- The mobile operator, which includes the historical dealer (Algeria Telecom) and the three operators Orascom Telecom Algeria, Algeria Telecom for Mobile, and Wataniya Telecom Algeria.

- Fixed dealer of Algeria Telecom and the Algerian Telecommunication Association.

A number of measures have been taken, taking into account interconnection agreements, in order to protect network operation, maintain network integrity, and service compatibility.

The following summarizes the situation of telecom operators and providers in the following table (see table 4):

There has been no major change in the number of operators and providers in the telecom market, except for call centers whose numbers have increased from 69 to 82, 13 more than the year 2015 (ARPT, 2016).
Table 4. Summary of the Number of Operators and Service Providers

\begin{tabular}{|c|c|c|c|c|c|c|}
\hline segment & 2011 & 2012 & 2013 & 2014 & 2015 & 2016 \\
\hline phone fixed & 1 & 1 & 1 & 1 & 1 & 1 \\
\hline $\begin{array}{c}\text { mobile phone } \\
\text { GSM }\end{array}$ & 3 & 3 & 3 & 3 & 3 & 3 \\
\hline mobile phone 3G & 0 & 0 & 3 & 3 & 3 & 3 \\
\hline mobile phone 4G & - & - & - & - & - & 3 \\
\hline VSAT & 3 & 3 & 3 & 3 & 3 & 3 \\
\hline GMPCS & 3 & 3 & 3 & 3 & 2 & 2 \\
\hline VOIP operator & 3 & 3 & 3 & 3 & 3 & 3 \\
\hline ISP & 19 & 19 & 17 & 20 & 23 & 27 \\
\hline AUDIOTEX & 7 & 6 & 6 & 7 & 8 & 8 \\
\hline call center & 75 & 71 & 61 & 64 & 69 & 82 \\
\hline
\end{tabular}

Source: ARPT $(2014,2016)$

\section{The Impacts of the Openness of Telecommunication Sector}

We must emphasize on the openness of this sector had a great impacts and effects on some economic fields and areas, such as the military defense, the industrial and agricultural sector, the educational sector and others, since that many economic sectors have benefited from this availability of the telecommunication sector, despite the fact that such field dis still has a disability from some problems and still lag behind other countries, even some regional ones such as Morocco and Tunisia.

Also, this data shows us that the Algerian experience in this sector, after many years of living in the centrally economic model, have shown and demonstrated that it was the time to liberalize and open this sector, not only to national operators but also to foreigners ones, taking, surely, the examples of others countries who have tried the same initiative and reaching some goods scores in many sectors.

We add that the impacts have also been felt by domestic customers and national enterprises, according to the some reactions and satisfactory feeling among managers and deciders, but also according to the growing number of users from year to another, which has been remarkably exploited by the national deciders to increase the numbers of materials in fixed telephone, internet and others technological services, taking into account that the recent world is composed of technological, numerical and digital world for the best of national o economy, but also to economic agents, mainly enterprises, companies, customers, investors, savers, services and others, and this has been highly approved and recommended by international institutions, like the World Band, The Monetary Financial Fund and others. 


\section{Conclusions and Recommendations}

Reform is a continuous process that changes with the development of markets and is not just an applying to one set of rules, This is what we learned from our study of the telecommunications sector owned by the government sector, and with the emerge of restructuring options for the public sector, namely privatization, corporate creation and liberalization, the need for an independent arbitrator has become urgent and these changes represent the first step towards new policies.

Algeria is one of the countries that have sought to do so by reforming its telecommunications network, which was not consistent to run this sensitive sector, despite the sequence of its development plans, this sector was unable to solve the problem of delay, which was due mainly to several factors, including:

- Saturation of the telephone numbering scheme;

- The delay in the completion of the buildings, which were supposed to receive a large number of equipment programmed, and this is due to weak national institutions in the field of studies and construction, which did not take the sector projects seriously;

- The rest to be realized takes the lion's share for the next plan;

Investments remain insufficient for the needs of the sector.

All of these factors have led to an increase in the number of pending applications, poor quality of service to citizens in particular and to the institution in general, but things have changed thanks to the new law on the telecommunications sector, which opened the door to private investors after thirty-eight years of monopoly, The state granted the private sector licenses, which led to the strengthening of supply in this area. Since 2001, the regulatory authority has started to issue licenses for exploitation, from fixed and mobile phones (GSM), licensing of internet service providers, audiotex, and others.

Algeria is planning for future policy settings that are compatible with technological change, in order to get rid of its restrictions and to reach the rank of countries with the same level of development and to open up promising prospects for the future, therefore, the following recommendations are required:

- Stimulate investment in the telecommunications sector as an influential force in growth and economic development at the national level;

- Adopting policies and strategies to take into account the changing environment such as the transform from traditional to full-fledged network convergence of voice, data and video images to keep pace with global developments;
- Exploiting the potential of technology to expand the fiber optic network to apply e-government, which paved the environment of information technology.

\section{REFERENCES}

[1] Abdou Salam Sall (2007), Regulation in a Development Context: Regulatory Forum II, Editions of the Regulatory Forum, Dakar, P 45.

[2] Arab Book (2008), Communication Policies in the Arab Region, Online Paper. Retrieved from: www.ito.org.eg/ara bbook, 12/07/2008:11H30

[3] ARPT (2005), Regulatory Authority for Posts and Telecommunications, Annual Report, No 3, P 9. Retrieved from: https://www.arpt.dz/fr/doc/pub/raa/raa_2005.pdf.

[4] ARPT (2006), Regulatory Authority for Posts and Telecommunications, Quarterly Bulletin, No 5\&6, P 19. Retrieved from: https://www.arpt.dz/fr/doc/pub/bult/arpt_b ulletin_N5-6 fr.pdf.

[5] ARPT (2013), Regulatory Authority for Posts and Telecommunications, Mobile Market in Algeria Observatory, P 05. Retrieved from https://www.arpt.dz/ar/ doc/obs/etude/2013/Observatoire_Mobile_2013.pdf

[6] ARPT (2014), Regulatory Authority for Posts and Telecommunications, Press Release, 30 November 2014, p 8. Retrieved from: https://www.arpt.dz/fr/doc/actu/com/20 14/dossier presse 2014.pdf.

[7] ARPT (2014), Regulatory Authority for Posts and Telecommunications, Annual Report, pp 8-33. Retrieved from: https://www.arpt.dz/fr/doc/pub/raa/raa 2014.pdf.

[8] ARPT (2015), Regulatory Authority for Posts and Telecommunications, Annual Report, PP 35- 37. Retrieved from https://www.arpt.dz/fr/doc/pub/raa/raa 2015.pdf.

[9] ARPT (2016), Regulatory Authority for Posts and Telecommunications, Statement of Accounts Of activities (as at 31 December 2016). Retrieved from https://www.arpt.dz/fr/doc/actu/com/2017/ARPT_Bilan_2 016-29_MARS_2017_Fr.pdf.

[10] Baye Samba Diop (2012), Telecommunications Regulation in Senegal, (Doctoral Dissertation, Option Regulation, cheikh Anta Diop university, doctoral School, Sciences Political and Economic and Management), Dakar, p 42-61. Retrieved fromwww.osiris.sn/download.php?fic=these_fin ale bsdlast.pdf

[11] Berry Nourredine (2010), Regulation of Public Services: the Telecommunications Sector, Academic Review on law Research, No 2, Abderrahmane Mira University, Faculty of Law, Bejaia- Algeria, PP 13-24.

[12] Djilali Benamrane, Bruno Jaffré, \& François Xavier Sanghrare, the Telecoms Between Public Good and Commodity, (Article Written by José DO-Nascimento: the Development of Mobile Telephony in Africa), Collective Book, Editions Charles Leopold Mayer, France 2005, p 178. 
[13] Gerald E. Caiden (2009), Administrative Reform, Aldine Transaction, a Division of Transaction Publishers, New Brunswick (U.S.A) and London (U.K), (Second Paperback Printing), p 67.

[14] Imed limam (2003) Challenges and Reforms of Economic Regulation in MENA Countries, an Economic Research Forum, Edition the American University in Cairo Press, Egypt, P 60.

[15] Kjell A. Eliassen \& John From, the Privatization of European Telecommunication, Asghgate Publishing Limited, England, 2007, Chapter5, P 75.

[16] LIDO (1995), Report on Study days of Post and Telecommunication (PTT) Sector Managers, Higher Institute of Management and Planning, Bordj el Kiffane-Algeria, 16-17 June 1995.

[17] Mark D.J.Williams, Rebecca Mayer, \& Michael Minges, Africa ICT Infrastructure Building on Mobile Revolution, Directions in Development Infrastructure, the World Bank, Washington, D.C, 2011, p200.

[18] Mihoub Mezouaghi (2005), Liberalization of Telecommunications Services in the Maghreb: Institutional Transition and Performance, Institute of Research on Contemporary Maghreb (IRMC), AFD NO 23 (French Development Agency Department of Research), see 40-51, Retrieved from https://www.afd.fr/fr/liberalisation-des-ser vices-de-telecommunication-au-maghreb-transition-institut ionnelle-et-performances.

[19] MPT (1981), General Data on the Telecommunications Network, Internal Document, Ministry of Postal and Telecommunications.

[20] MPT (1985), the Telecommunications: Outlook 1990 and Balance Sheet 1962 - 1977, Internal Document, Ministry of Postal and Telecommunications.

[21] Nicolas Thirion (2000), Privatization of Public Enterprises, Market Economy and Transformation of State Legal Systems: an Inevitable Process? Review Pyramids the Public Administration Research Laboratory, Brussels, No 2, p 95.

[22] Riad Dahel (2001), Telecommunications Privatization in Arab Countries: An Overview, Arab Planning Institute, Kuwait, p 16.

[23] Thierry Penard \& Nicolas Thiron (2007), Regulation in Telecommunications: a Cross-Cutting Approach to Economics and Law, Brussels, Edition Larcier, pp 87 -124.

[24] Toupictionnaire: the Dictionary of Politics (2017). In MIMS Online. Retrieved 15, 07 from http://www.toupie.org/Dicti onnaire/Privatisation.htm

[25] United Nations (2009), Economic Information Report, Trends and Forecasts, conference on Trade and Development, New York and Geneva.

[26] Walter Amedzro St-hilaire (2011). Management of State Telecoms Mutating Challenges and Strategies, Press of the University of Quebec, Canada, p2. 